\title{
ARTICLES
}

Klio. Czasopismo poświęcone dziejom Polski i powszechnym

PL ISSN 1643-8191, t. 55 (S)/2020, s. 279-305

(c) (1) $\Theta$

http://dx.doi.org/10.12775/KLIO.2020.044

\section{Katarzyna PęKacka-Falkowsha*}

\section{The anatomical-surgical and engraving instruments of the Danzig physician Christoph Gottwald}

\begin{abstract}
Summary: Christoph Gottwald (1636-1700) was one of the most important Danzig doctors and collectors to live in the $17^{\text {th }}$ century. Gottwald was a graduate of Leiden University and a student of Frans de la Boë, known as Sylvius, becoming a doctor of medicine and philosophy as well as being an engraver. His legacy has been preserved among others in seven works of chalcography, which together with an array of surgical-anatomical instruments present also pigments, microscopes as well as a vivisection table that constituted a part of his scientific workshop. This constitutes a unique piece of evidence depicting the research of a naturalist living in the Polish-Lithuanian Commonwealth in the second half of the $17^{\text {th }}$ century.
\end{abstract}

Keywords: Christoph(orus) Gottwald (1636-1700), Musaeum Gottwaldianum, natural history collections - Royal Prussia, natural history - the Polish-Lithuanian Commonwealth, history of medicine - Danzig (Gdańsk) - 17th century, history of anatomy

- The paper was originally published as Instrumenty chirurgiczno-anatomiczne i rytownicze gdańskiego lekarza Christopha Gottwalda (1636-1700), "Klio" 2018, vol. 46, issue 3, pp. 157-183, DOI: 10.12775/KLIO.2018.037.

The Department of the History and Philosophy of the Medical Sciences, Poznan University of Medical Sciences, Przybyszewskiego 37a St., 60-356 Poznań; pekackafalkowska@ump.edu.pl; ORCID: 0000-0003-2068-7957. 
Magna est artis anatomicae ob suas ad sensuum externorum tribunal decernendas demonstrationes sensibiles, ideoque manifestas, certasque praesentia et gloria. Christoph Gottwald (1661)

B eginning from the Middle Ages, in works devoted to surgery, one can encounter images depicting surgical instruments along with their descriptions. The most famous of these come from the works of, among others, surgeons such as Abulcasis, ${ }^{1}$ Guy de Chauliac, ${ }^{2}$ Ambroise Paré ${ }^{3}$ or Fabricius Hildanus. ${ }^{4}$ In the $17^{\text {th }}$ century there appeared separate publications devoted exclusively to surgical instruments, the authors of which described in detail the individual instruments, discussing at the same time the procedures employed in their production and use. ${ }^{5}$

Surgical instruments, as is understood, also served anatomists during the performing of vivisections and autopsies. Suffice it to recall the famous print from De corporis humani fabrica libri septem by Andreas Vesalius, which depicts his use of anatomical-surgical instruments, ${ }^{6}$ as well as a short fragment from the introduction where the anatomist explicitedly states that surgery as well as anatomy are inseparable fields, essential

1 Plates IV-V. Fig. 1-102: Die chirurgischen Instrumente der Araber bei Abulkasim, in: E. Gurlt, Geschichte der Chirurgie und ihrer Ausübung, vol. 1, Berlin 1898 [insert].

2 Ibidem, Plate VI. Guy de Chauliac (Fig. 1-22), vol. 2 [insert].

3 Ibidem, Plates XVI-XX.

4 Ibidem, Plates XXIV-XXV, vol. 3 [insert].

5 Cf. C. Solingen, Manuale Operatien der Chirurgie, Beneffens het Ampt en Pligt der Nroedvrouwen, Midsgaders' Besondere Aenmerkungen De Vrouwen en Kinderen betreffend, Amsterdam 1684; K. Grooss, Cornelis Solingen: A Seventeenth-century Surgeon and His Instruments, Leiden 1990; J. Schmid, Instrumenta Chirurgica, Das ist: Kurtze und gründliche Beschreibung / aller und jeder Chirurgischen Instrumenten / so in diesem Tractat begriffen: sampt deroselben ins Kupffer gebrachte eygentliche Abbildung, Augsburg 1693.

$6 \quad$ Andreae Vesalii Bruxellensis, scholae medicorum Patavinae professoris, de Humani corporis fabrica Libri septem [ex officina Ioannis Oporini], Basileae [Anno salutis reparatae 1543], p. 235; http://dx.doi.org/10.3931/e-rara-20094 [access: 01.03.2018]. This representation of instruments has permenanetly entered into popular culture. It was employed, among others, in the movie by David Cronenberg Dead Ringers (1988). 
to all physicians, although for centuries - held in contempt by them as artes vulgares. ${ }^{7}$ Somewhat simplifying matters and avoiding details, it follows to state that along with Vesalian reform of anatomy, including here research carried out by a doctor performing the dissection himself, was to become a permenant feature of the academic curriculum for those studying medicine; with its origins in the universities of Southern Europe with its gradual spread to academic establishments in the Netherlands, Denmark and Germany. ${ }^{8}$ In the subsequent two centuries illustrations presenting the instruments employed by medics performing dissections were to become something obvious in anatomical publications. ${ }^{9}$

These were also an important element in drawings depicting university anatomical theatres and hospital morgues that served as dissection venues. ${ }^{10}$ It also follows to recall that from the $17^{\text {th }}$ century onwards autopsies and vivisections in Protestant countries constituted part of the educational programme at many medical faculties. ${ }^{11}$ An important role was played in this process by activities at Leiden University, ${ }^{12}$ willingly attended

7 Ibidem: „Haec nanque cuum prius a medicis unicem excoleretur, ipsique in hac adipiscenda omnes neruos intenderent, tum demum miserem collabi coepit, quum ipsi manuum munus ad alios reiicientes, Anatomen perdiderunt", http://www3. biusante.parisdescartes. fr/vesale/index. 1 as? $\mathrm{e}=2 \& \mathrm{p} 1=00004 \& \mathrm{a} 1=\mathrm{i} \& \mathrm{p} 2=00004 \& \mathrm{a} 2=\mathrm{f}$ $\& v 1=00302 \_1543 \times 00 \& v 2=00302 \_1543 \times 00 \& c 1=2 \& c 2=2$ [access: 01.03 .2018 ].

8 For more on the subject of this very process cf. e.g. A. Cuningham, The Anatomist Anatomis'd: An Experimental Discipline in Enlightenment Europe, Burlington 2010.

9 Cf. J. Banister, Anatomical Tables, Uni. of Glasgow, MS Hunter 364 (V.1.1), http:// special.lib.gla.ac.uk/manuscripts/search/results_ca.cfm?ID=35232 [access: 01.03.2018]; J. A. Kulmus, Anatomische Tabellen daraus des gantzen menschlichen Körpers und aller dazugehörigen Theile Beschaffenheit und Nutzen deutlich zu ersehen.... Nebst dazu gehörigen Kupffern gestellet hat, Danzig 1764 (frontispiece).

${ }_{10}$ For example, the colourful representations of the anatomical theatre at Ospedale della Consolazione in the times of Giovanni Guglielm Riva; Rome, Museo Storico Nazionale Dell'Arte Sanitaria; numerous representations of the Leiden anatomical theatre in the 17th century.

11 A. Cuningham, The Anatomist Anatomis'd, passim.

12 Cf. T. Huisman, The Finger of God: Anatomical Practice in 17th-century Leiden, Leiden 2009; D. de Moulin, A History of Surgery: With Emphasis on the Netherlands, London 1988, pp. 64-286. 
by students from Royal Prussia during the course of their medical travels. ${ }^{13}$ One of those neophytes in attendance while studying at Leiden in the 1660s was the Danzig citizen, Christoph Gottwald (1636-1700). ${ }^{14}$ Seven copper etchings have been preserved in the legacy left by this doctor of philosophy and medicine, a collector as well as an engraver. They present, besides various anatomical-surgical instruments, also pigments, microscopes and a vivisection table that comprised his scientific workshop (Tables C-I). These objects were preserved in a walnut wooden chest (Table B) located in Gottwald's private anatomical surgery or theatre (Table A), which besides a library, garden and observatory was a supplement of his Musaeum, that is his collection. ${ }^{15}$ As a graduate of Leiden University ${ }^{16}$ Christoph Gottwald

13 M. Pawlak, Studia uniwersyteckie mtodzieży z Prus Królewskich w XVI-XVIII w., Toruń 1988, pp. 158-159; K. Pękacka-Falkowska, The Medical Faculty at the University of Leiden and its Graduates from the Polish-Lithuanian Commonwealth Some Introductory Remarks, "Bulletin der Polnischen Historischen Mission" 2020, Nr. 15, pp. 97-138, DOI: http://dx.doi.org/10.12775/BPMH.2020.004..

${ }_{14}$ Matriculated on the 17th of September 1660 at the Faculty of Medicine. Album studiosorum Academiae Lugduno Batavae MDLXXV-MDCCCLXXV; accedunt nomina curatorum et professorum per eadem secula, ed. W. N. Du Rieu, Hagae 1875, pp. 483, 1535. For an extensive biography of Christoph Gottwald cf. K. Pękacka-Falkowska, Wokót kolekcji przyrodniczych w Rzeczypospolitej Obojga Narodów. Part I: Christoph i Johann Christoph Gottwaldowie oraz ich gdańskie muzeum, "Kwartalnik Historii Nauki i Techniki" 2018, vol. 63, no. 2, pp. 51-97, DOI: 10.4467/0023589XKHNT.18.010.9463. Also for an overview of the subject literature up to 2017.

15 On Musaeum Gottwaldianum see further: K. Pękacka-Falkowska, About the Sale of the Museum of the Gottwalds: Johann Philipp Breyne and His Correspondents, "Zapiski Historyczne” 2017, vol. 82 (3), pp. 31-47, DOI: 10.15762/ZH.2017.69; ead., Wokót kolekcji przyrodniczych; D. D. Novgorodova, Ot muzeya Gottval'da $k$ mineral'nomu katalogu kunstkamery, in: Materialy semnadtsatykh chteniy pamyati I. M. Tronskogo. Indoyevropeyskoye yazykoznaniye i klassicheskaya filologiya - XVII, Sankt Petersburg 2013, pp. 636-653. Cf. equally the PhD thesis of Daria D. Novgorodova devoted to the beginnings of tsarist mineralogical collections: Katalogi mineralnogo kabineta Kunstkamery XVIII v.: kulturnaja istorija kollekcii (Moscow 2017), http://www2.rsuh.ru/binary/ object_19.1514194128.96851.pdf [access: 01.03.2018].

16 During his degree Gottwald took part in 1661 in the public disputation exercitii gratia: Disputatio VIII. De vasis lymphaticis ac lympha. Resp. Christophoro Gottwald DantiscoPrusso, 19. Mart. 1661. The contents of which are published in: Francisci De Le Boe, Sylvii, Medicinae Practicae inAcademia Lugduno-Batava Professoris. Disputationum Medicarum 
was not only a doctor but also a representative of anatomia nova. As opposed to the descriptive anatomy of the previous century here emphasis was placed on the physiological processes taking place in the bodies of people and animals. Following the worksof William Harvey and Descartes as well as the discovery of lymphatic ducts and lacteals/lacteal glands by Gaspare Aselli, Thomas Bartholin and other academics, these new anatomists, fascinated by mechanistic philosophy, willingly threw themselves into experimental methods, primarily vivisection. ${ }^{17}$ They equally enthusiastically made use of microscope methods, as they broadened their ocular knowledge. As a result, their interests were also aroused by new techniques of preserving and coloring of vessels, fibres (tissue) and organs, ${ }^{18}$ new anatomical instruments, including syringes, ${ }^{19}$ as well as new ways of depicting the objects studied (including the compiling of both drawings or sketches as well as copperplates). ${ }^{20}$ The aim of the 'new anatomist' was not merely to describe the construction of a dissected body. His role was also to discover, comprehend and describe the processes comprising the entirety of elements of the said body. In this way the subject of anatomical cognition changed its character from the static to the dynamic: functional anatomy ${ }^{21}$ started

Decas. Primarias corporis humanifunctiones naturales. nec non febrium naturam, exanatomicis. practicis \& chimicis experimentis deductas. complectens: Omnibus ad Leidense exemplar fideliter conformatis, Lipsiae 1674, pp. 127-160. He was also to have defended on the $11^{\text {th }}$ of July 1662 his doctorial thesis: Disputatio de Melancholia Hypochondriaca (Lugduni Batavorum 1662). For more about him when residing in Leiden, cf. Olai Borrichii Itinerarium, 1660 -1665: The Journal of the Danish Polyhistor Ole Borch, Copenhagen 1984, vol. 1, pp. 60, 99, 213-216; Vol. 2, pp. 11, 23; vol. 3, pp. 108-116.

${ }_{17}$ On the scope of vivisection in the course of anatomical research in the $17^{\text {th }}$ century, cf. M. D. Meli, Early Modern Experimentation on Live Animals, "Journal of the History of Biology" 2013, vol. 46, pp. 199-226, DOI 10.1007/s10739-012-9327-7; G. A. Lindeboom, Dog and Frog: Physiological Experiments at Leiden During the Seventeenth Century, in: Leiden University in the Seventeenth Century: An Exchange of Learning, eds. T. H. Lunsing Scheeurler, G. H. M. Posthumus Meyes, Leiden 1975, pp. 278-293.

${ }_{18}$ H. Cook, Matters of Exchange: Commerce, Medicine, and Science in the Dutch Golden Age, New Haven-London 2007, pp. 268-276.

${ }_{19}$ T. Huisman, The Finger of God, p. 67; A. Cuningham, The Anatomist Anatomis'd, pp. 151, 237.

20 Reclams Handbuch der künstlerischen Techniken, vol. 1, Stuttgart 1998, p. 276.

21 Today equated with physiology. 
to supplement and sometimes to outstrip descriptive anatomy. For Dutch academics, including Jan van Horne as well as Frans dele Boë Sylvius, for whom our student from Danzig was to become a colleague and protégé, ${ }^{22}$ this was the most important foundation of medicina quod est ars et scientia. And indeed, in Leiden at the time when Gottwald studied there, anatomia nova had many adherents and promoters.

What is important is that Gottwald, besides the fact that he was a doctor and anatomist, was also a most accomplished artist. From his youth he had taken a love for drawing, etching, gliptique and art work made from ivory. As he recalled in the personal details which he noted down at the end of his life, ${ }^{23}$ already while studying at the Danzig Academic Gymnasium he decided on two parallel educational paths. On the one hand, while in Danzig he trained under the supervision of local artists and craftsmen, including Samuel Nidenthal, ${ }^{24}$ while on the other hand he attended lectures on natural history including medicine conducted by Lorenz Eichstaedt ${ }^{25}$ and

22 Cf. Nicolaus Steno: Biography and Original Papers of a $17^{\text {th }}$ Century Scientist, eds. and transl. T. Kardel, P. Maquet, Springer Science \& Business Media, Leiden-New York-Heidelberg 2012, p. 431.

23 Personalia, in: Christus Im Leben und Sterben, Als der entseelte Cörper Des [...] Hn. Christophori Gottwaldts M.D. und Hochverordneten Practici, auch Physici Ordinarii bey dieser Stadt, Bey Volckreicher Begleitung Anno M.DCC d. 12 Januarii In seine RuheCammer beygesetzet worden [...] In der Ober-Pfarr-Kirchen zu St. Marien fürgestellet von Constantino Schützen [...], Gedani 1700.

24 Cf. Annex. Samuel Niedenthal (1620-before 1666) - a painter, engraver and etcher from Erfurt. In 1635 he came to Danzig and was accepted to study at the workshop of Jacob Liscornet Senior. After unsuccessful attempts to gain a municipal funding he left the city, to return only in 1643 and become a guild master (for the years 1660-1661 he was its elder). He produced, among other things, sketches of animals, including of birds living in Royal Prussia (technique: coloured chalk). His alumnus and pupil was Andreas Stech. Cf. K. Jackowska, Nidenthal Samuel, in: Stownik artystów polskich i obcych w Polsce dziatających, vol. 6: N-Pc, Warszawa 1998, pp. 53-54; J. Tylicki, Rysunek gdański ostatniej ćwierci XVI i pierwszej potowy XVII wieku, Toruń 2005, pp. 89-91, 216-236.

25 Lorenz Eichstaedt (1596-1660) - a Danzig citizen, professor of Medicine, Physics and Mathematics at the Danzig Academic Gymnasium, a Danzig city physician (Stadtphysicus) interested in, among other things, botany. Cf. Vitae medicorum Gedanensium Ludwiga von Hammena i Valentina Schlieffa, ed. and trans. B. Siek, A. Szarszewski, Gdańsk 2015, pp. 93-99. 
David Stoll. ${ }^{26}$ Both of these two fields of interest - natural history and artistic craft - were to become in the future the main pillars of his academic activity.

An exceptional example of the realisation of both of Gottwald's passions are the copper-etching prints that depict the research instruments in his possession. These engravings constitute a fragment of a much bigger album compiled and edited by Johann Philipp Breyne in February and March 1714 following the sudden death of Johann Christoph, the physician's son. Gottwald junior's widow, who like his father had been a doctor of philosophy and medicine, allowed Breyne to work on what had been left to her by the late husband as inheritence in her father-in-law's will, and here the matter concerned both his manuscripts and his sketches, copperplates and drawings. ${ }^{27}$

The album from which the prints come was of a commercial design. Breyne would send it to potential customers of these Gottwald copperetched templates. ${ }^{28} \mathrm{He}$ also sent it to his friends from England and German-speaking countries as a supplement to the Musaeum Gottwaldianum auction catalogue. ${ }^{29}$ The copperplates with the monogram SD (Tables A, B,

26 David Stoll, d. 1657 in Danzig, a physician, he studied in among other places Basel, Padua and Leiden. He obtained the title of doctor of philosophy and medicine in 1652. For more see: ibidem, pp. 84-85.

27 Cf. J. H. Lochner, M. F. Lochner, Rariora musei Besleriani quae olim Basilius et Michael Rupertus Besleri collegerunt: aeneisque tabulis ad vivum incisa evulgarunt [Nuremberg: s.n.], Anno O.R. 1716, p. 61; Johannes Philippus Breynius M.D. et Reg. Soc. Angl. Soc. Rerum Anatomicarum et Naturalium Amatoribus S., in: K. Pękacka-Falkowska, Wokót kolekcji przyrodniczych, pp. 88-92.

28 K. Pękacka-Falkowska, Wokót sprzedaży. There, among others, a review of the bid letters. See, also the letter of Johann Philipp Breyne in Dutch attached to the album kept at the Library of Congress in Washington (Musaeum Gottwaldianum, QL71.G6 G6 fol.; the manuscript in a study by the author). It is unknown who was the addressee of the letter and therein the album edition. The copy itself was to make its way to the Library of Congress in 1864 (accessed on: 26 $6^{\text {th }}$ of May) after the transfer by the Smithonian Institution of a deposit of 40000 volumes (April 1864). I would like to thank Michael North, Head, Reference and Reader Services Rare Book and Special Collections Division, for this information.

29 Musaeum Gottwaldianum, sive catalogus rerum rariorum, tam naturalium, quam artificialium, longa annorum serie. Cur aque et sumtibus haud exiguis collectarum, à viris 
E, G) were more than likely performed by Samuel Donnet, ${ }^{30}$ quite possibly on the basis of sketches or earlier accessible plates created by Gottwald. ${ }^{31}$ Those which do not have a monogram could have been independently rendered by the physician.

Breyne divided the prints from Gottwald's legacy into two thematically cohesive parts, and entitled them Musaeo curioso Rerum naturalium and Musaeo Anatomico. ${ }^{32}$ The first of the albums chiefly contained images of shells, starfish, corals, as well as other marine creatures. The second was mainly a collection of anatomical drawings. Breyne supplied each of these

d.v. excellentissimis experientissimisque, D. Christophoro Gottwaldio, Med. D. \& Phisico Gedanensi, Patre \& D. Joh. Christoph Gottwaldio, Med. D. filio, quas publica auctione in aedibus gottwaldianis Anno 1714. d. [...] Divendet Georgius Mattern. Typis Joh. Zachariae Stolli [Gedani 1714].

30 Samuel Donnet - a copper engraver active in Danzig from 1699 to 1734. Cf. R. Bergau, Die Danziger Kupferstecher Samuel und Johann Donnet, "Archiv für die zeichnenden Künste mit besonderer Beziehung auf Kupferstecher- und Holzschneidekunst und ihre Geschichte" 1867, vol. 13, pp. 145-151.

31 In 1694 at Gottwald's surgery, and therefore more than likely in his library, one could have seen, among others: " 5 . Omnia corpora Mathematica von holtz Elffenbein selbst gemacht von H. Gottwalden in einem Schatoll mit sonderbahren schloss. 6. Regalia Medica und Nahme in Kupfer gestochen. 7. Zeichnungsbuch von allerhand sachen”. G. Kohfeldt, Eine akademische Ferienreise von Rostock bis Königsberg im Jahre 1694, "Baltische Studien" 1905, vol. 9, p. 24

32 In Breyne's library auction catalogue next to the abbreviated titles were also full titles: Chph. Gottwaldi Thesaurus Conchiliorum Tabb. Aeneis XLIX summa deligentia constans, quarum priores 6 stellas marinas \& Corallia, caeterae testacea univalvi turbinata representant, Gedaci c. praef. Joh. Phil. Breynii MST andEjusd. LXII. Tabulae aenae artificiose sculptae, varias curiosas observaat. Anatom. in homine \& brutis complectentes, pro Museo Anatomico reservatae, Gedani c. Praef. \& Explicatione Tabularum. See Bibliothecae Breynianae Pars Prior. Sive Catalogus Librorum Philologico-PhilosophicoHistoricorum, Itinerariorum, Inprimis autem Medicorum, Botanicorum Et Historiae Naturalis Scriptorum \&c. Rariorum, Quam Magno Studio Et Sumptu Sibi Comparavit D. Johan. Philipp. Breynius. Acad. Imper. Natur. Curiosorum, Nec Non Reg. Societ. Anglic. Scient. Sodalis. Publica Auctionis Lege In Aedibus B. Possessoris (in der Langgasse.) D. XV. Julii A. MDCCLXV. Distrahende Per Joan. Godofr. Barthelsen, part 1, p. 20. It also seems that Musaeo Anatomico was, in Gottwald's intention, to have been the first richly illustrated anatomical atlas to be published by a citizen of Danzig, and consequently - if the project had seen fruition on the part of the physician - the work would have preceded by almost a quarter of the century the work by Johann Adam Kulmus Anatomische Tabellen. 
albums with a manuscript introduction along with a list of the illustrations therein contained. ${ }^{33}$ In the copy of Musaeum Anatomicum preserved at the Boerhaave Museum in Leiden there are also preserved the legends of a large number of the attached chalcography. Some of the descriptions were in the possession of Gottwald. The rest was compiled by Breyne on the basis of his (currently lost) notes. ${ }^{34}$

The first one depicts the interior of Gottwald's private anatomical surgery or theater (Tab. A). This surgery was situated on the second floor of the doctor's Danzig town house and, if one is to believe the words of Carl Arndt, a student of Theology, who visited Gottwald's house in 1694, then he found there several already prepared skeletons. From the large windows stretched a marvellous view onto an 'enchating garden' with a wonderful orangery and grotto. Yet, in the drawing there are no skeletons; the only skeleton is the one that crowns the hanging cabinet. In accordance with Arndt's words, such a cabinet was to have been located in one of the rooms on the first floor of the house and was to have had speculum vitae humanae painted on the little door, so the small wooden skeleton was to have been the personification of death. ${ }^{35}$ Equally other objects presented in the copperplate - including ostrich eggs turned into globes, a rhinoceros horn, tortoise shells or lizards preserved in pure alcohol - were exhibited in other rooms in the doctor's house. The Musaeum Anatomicum drawing seems, consequently, to be conventional in form and combines two sorts (ones constantly permeating each other) of space essential for the scientific activities undertaken by the Danziger. On the one hand, the matter concerns the exhibition-study-studio space, that is the Musaeum itself, while on the

33 For both introductions see: Johannes Philippus Breynius M.D. et Reg. Soc. Angl. Soc. Rerum Anatomicarum et Naturalium Amatoribus S. oraz Johannes Philippus Breynius M.D. et Reg. Soc. Angl. Socius Rerum Anatomicarum et Naturalium Amatoribus Salutem, in: K. Pękacka-Falkowska, Wokót kolekcji przyrodniczych, pp. 88-92.

34 The author of this article is preparing an edition of the Leiden manuscript within the framework of a Van de Sande Fellowship at the Scaliger Institute (2019).

35 G. Kohfeldt, Eine akademische Ferienreise. 
other, the demonstrative-experimental space, namely the private vivisection and dissection room, or anatomical theater. ${ }^{36}$

One can see under one of the Musaeum Anatomicum windows a large chest which stands on a small pedestal covered with a thick material with tassels. This is also illustrated on another copperplate engraving: this time it is presented as open and in a longitudinal section (Tab. B). In a sevenlevel chest of walnut are kept Gottwald's surgical-anatomical instruments as well as other instruments used in research.

Tables C-I chiefly show metal, silver and leaden tools which Gottwald used when performing autopsies and vivesections. To date historians have not been able to unanimously say what specific instruments are presented by which boards. ${ }^{37}$ Thanks to Breyne's descriptions one is able to identify each instrument individually, while in certain cases one can also point to their prototypes, for example the surgical lancet described by Johannes Scultetus in his posthumously published Armamentarium chirurgicum (1655). There is absolutely no possibility with regard to any other physician, anatomist, or surgeon living in the Polish-Lithuanian Commonwealth during the second half of the $17^{\text {th }}$ and first half of the $18^{\text {th }}$ centuries to recreate the precise range of anatomical-surgical instruments and equipment employed within his workshop and consequently the most important elements of his trade. ${ }^{38}$

${ }^{36}$ S. Siemer, Geselligkeit und Methode. Naturgeschichtliches Sammeln im 18. Jahrhundert, Meinz 2004, p. 172.

${ }^{37}$ E.g. Jakub Jakubowski wrote about this in an extremely vague way as "a hand saw, chisels, hammers, gimlets, pincers, scissors." J. Jakubowski, "Musaeum Gottwaldianum" ze zbiorów Biblioteki Politechniki Gdańskiej i wydawnicze losy dzieta Christophorusa Gottwalda (1636-1700) w XVIII w., "Porta Aurea. Rocznik Zakładu Historii Sztuki Uniwersytetu Gdańskiego" 2015, vol. 14, p. 94, footnote 9. Cf. S. Siemer, Geselligkeit und Methode, pp. 172-174, 295.

${ }^{38}$ On the frontispiece of Johann Adam Kulmus's work are presented the anatomical instruments used by him, nonetheless this is a simplified representation. It is also not accompanied by any description whatsoever (cf. footnote 9). In Breyne's auction catalogue of the collection from the 1760s his research instruments are vaguely mentioned, nevertheless the list encompasses specialised scientific items from the experimental sciences and astronomy broadly comprehended. There was an absence, however, of anatomicalsurgical instruments. Johann Philipp Brayne nachgelassenen berühmten Naturalien Cabinets 
Here it is worth noting that in the Early Modern period and consequently at a time before standardisation in terms of production methods, something that was to be only ushered in with the industrial era, surgical-anatological instruments were produced by specialised craftsmen with a wide knowledge of metal working. ${ }^{39}$ Those who were to use them as the actual producers were to constantly experiment with such objects, willingly modifying them or improving their effectiveness. Anatomists and surgeons either ordered new sets and/or elements required by them for their instrument collections directly from metal-working craftsmen, or tried to buy them at auctions of the possessions of other dead representatives of their profession. ${ }^{40}$ Otherwise they were forced to borrow them, which obviously caused much inconvenience and could frequently result in a refusal. ${ }^{41}$ It is also important to remember that instruments of this ilk were extremely costly. And so in the spring of 1714 Christian Heinrich Erndtel, the royal physician to Augustus II the Strong, through the intermediacy of Breyne ordered a set of used surgical instruments, which were to cost him 10 gold ducats. ${ }^{42}$

In the case of the instruments in Gottwald's possession one may also advance the hypothesis that some of them had been purchased while he was

welches in Danzig in der Langgasse für baares Danziger Geld den 1765 etc., Danzig 1765, pp. 395-396.

${ }^{39}$ M. Rooseboom, Bijdrage tot de Geschiedenis der Instrumentmakerskunst in de Noordelijke Nederlanden, Leiden 1950, http://www.dwc.knaw.nl/wp-content/ bestanden/1950-Rooseboom-Instrumentmakerskunst.pdf [access: 01.03.2018].

${ }^{40}$ Literature on the subject of surgical-anatomical instruments when contrasted to what is available about other scientific instruments of the $17^{\text {th }}$ century especially astronomical (e.g. P. Rybka, Instrumentarium astronomiczne Heweliusza: geneza i rozwój konstrukcji, Wrocław 1987), is scant, with this applying as equally to Polish as foreign historiography. History of science works devoted to $17^{\text {th }}$-century surgical and anatomical instruments have been compiled by, among others, Ghislaine Lawrence and John Kirkup, though their texts are first and foremost of an inventory (and not an explanatory) nature.

${ }_{41}$ T. Huisman, The Finger of God, p. 29.

${ }^{42}$ Forschungsbibliothek (FB) Gotha, Chart. B. 786, ff. 145r-154v; ibidem, Chart. B 857b, f. 87; K. Pękacka-Falkowska, Wstęp, in: Ch. H. Erndtel, Dziennik podróży uczonej do Anglii i Holandii, trans. and eds. K. Pękacka-Falkowska, H. Bogusz, Warszawa 2018, p. 26. The research at FB Gotha was conducted thanks to the support of Herzog-ErnstStipendium der Fritz Thyssen Stiftung. 
still residing in Leiden in the 1660s and from the workshop of the craftsman Samuel van Musschenbroek, ${ }^{43}$ the founder of the famous van Musschenbroek 'dynasty'; an instrument maker about whom several decades later it was said: "[...] de eerste philosopische Instrumentmaker in ons Nederlandt, uijtvinder van Luchtpompen, Microscopia, Telescopia, anatomische Injicieerspuiten, en veele andere instrumenten." ${ }^{44}$ The air pump along with the anatomical-surgical instruments created by the representatives of this line was to enrapture the earlier mentioned Erndtel in the first decade of the $18^{\text {th }}$ century while on a visit to Leiden. ${ }^{45}$ Among others Regnier de Graaf, Jan Swaamerdam and Franciscus Sylvius were to employ in their research microscopes and syringes made by the van Musschenbroeks. The Musschenbroeks from the mid- $17^{\text {th }}$ century supplied research instruments (including anatomical-surgical items) to Leiden University, as well as to numerous naturalists and scientific societies in England, France, Denmark, Sweden etc. ${ }^{46}$ So why should some of Gottwald's instruments not have come from their workshop given that these were employed by equally his master and teacher as well as other alumni of his?

Equally interesting is the picture depicting the palette of pigments and the instruments used by the Danziger to produce his colour and blackand-white illustrations (Tab. H). The compasses, sharpener, pencils, quill, brushes and mixing pots next to the 10 sets of pigments best convey the look of Gottwald's work as an engraver and illustrator. For in the course of autopsies and vivisections this Danzig doctor would produce sketches

43 M. Rooseboom, Bijdrage tot de Geschiedenis, pp. 107-109; P. de Clercq, The Instruments of Science: The Market and the Makers, in: The History of Science in the Netherlands: Survey, Themes and Reference, eds. K. Van Berkel, A. Van Helden, L. C. Palm, Leiden 1999, p. $317 \mathrm{ff}$.

44 Qtd. in. C. A. Crommelin, Leidsche leden van het geslacht Musschenbroek, "Jaarboekje voor geschiedenis en oudheidkunde van Leiden en omstreken” 1939, p. 137.

45 Ch. H. Erndtel, Dziennik podróży uczonej, pp. 92-93.

46 C. A. Crommelin, Leidsche leden, pp. 134-149; P. de Clercq, Exporting Scientific Instruments around 1700 - 1. Introduction, "Tractrix" 1991, vol. 3, p. 82; idem, At the Sign of the Oriental Lamp. The Musschenbroek Workshop in Leiden, 1660-1750, Erasmus 1997; G. Wiesenfeldt, The Order of Knowledge, of Instruments, and of Leiden University, ca. 1700, in: Instruments in Art and Science: On the Architectonics of Cultural Boundaries in the 17th Century, eds. H. Schwarte, J. Lazardzig, Berlin 2008, pp. 222-234. 
on the basis of which the subsequent copperplates were to be created..$^{47}$ For example, the boards from Musaeum Anatomicum and published posthumously in 1782 Physikalisch-ökonomische Bemerkungen über die Bieber presenting a dissected beaver were produced on the basis of illustrations conducted by Gottwald during the research carried out in the 1680 s in conjunction with Ernst Gottfried Heyse, ${ }^{48}$ also a graduate of Leiden University, and first and foremost an alumnus of Charles Drelincourt, ${ }^{49}$ about whom Boerhaave wrote "nitidus incisor." 50 The pigments used by Gottwald corresponded to those used by the Danzig painter Samuel Nidenthal in his workshop. The Danzig doctor most likely used them to colour the cooperplate prints as well as to add colour to his sketches. Various shades and hues of reds, purples, blacks, whites, yellows, blues, and greens have been found in Gottwald's palette. Besides, Gottwald was keenly interested in iatrochemistry, while in his Musaeum objects connected with the mineral kingdom were in predominance, ${ }^{51}$ possibly amongst those painting materials employed by him the nonorganic ones prevailed. ${ }^{52}$ It is enough to recall that in the auction catalogue for his Musaeum there are, among others, "39. Species Terrarum, qvarum potissimum Pictoribus usus est." 53

47 K. Pękacka-Falkowska, Wokót kolekcji przyrodniczych.

48 Cf. Ch. Gottwald, Physikalisch-ökonomische Bemerkungen über den Bieber, Nürnberg 1782, p. 31 (vivisections conducted in March and April 1684); E. G. Heyse, Castor mas Gedani dissectus a. 1684 mense Aprili ab E.G.H. and Castoris foemellae dissectio instituta ab eodem, "Acta Eruditorum" 1684, vol. 3, pp. 360-364.

49 Cl. Dn. Caroli Drelincurtii, Experimenta anatomica, ex vivorum sectionibus petita. Edita per Ernestum Gottfried Heyseum, Dantiscanum, Leiden 1681.

50 G. A. Lindeboom, Bibliographia Boerhaaviana, Leiden 1959, p. 91.

51 K. Pękacka-Falkowska, Wokót kolekcji przyrodniczych.

52 On the pigments from Danzig workshops identified by means of spectroscopy and spectrometry see, for example: J. Olszewska-Świetlik et al., Wybrane materiaty w gdańskich warsztatach od XV do XVIII wieku w świetle badań metoda spektroskopii Ramana (RS), Toruń 2014; ead., Gdanski warsztat malarski schytku XVII i w XVIII wieku na przyktadach wybranych portretów przedstawiajacych protestanckich duchownych, Toruń 2010.

53 Musaeum Gottwaldianum, sive Catalogus, pages not numbered. Also in a handwritten list of minerals from the collection of Johann Theodor Klein "Fossilia Musei Kleiniani" are mentioned materials of various sorts serving artists (terrae pro Artificibus) and physicians (terrae pro Medicis) (PAN Biblioteka Gdańska, subsequently BG PAN, Ms 527, ff. 1r, 6v-6r). To the former belong: argilla (11 inventory items), tripela 
An important element of Gottwald's experimental workshop were also the microscopes and the suspended vivisection table (Tab. 1). The microscopes, like the anatomical-surgical instruments, may have come from the Leiden workshop of the van Musschenbroeks, yet also English and German producers may be considered. Gottwald used them during his natural history research, looking at, among others, insects under magnification, ${ }^{54}$ as well when carrying out and presenting his etchings on jewels and precious stones, amongst which "Kirchenstein darin viel Gesichter geschnitten in Elffenbein verwaret und Miscroscopie besehen: Der Churfuerst von Brandenburg und 16 andere." 55 The vivisection table was used to examine small animals: birds, dogs, cats etc. Already while in Leiden Gottwald assisted Sylvius in numerous demonstrations of anatomia nova. For example, in August 1662 he examined the heart of an aquatic raven along with, among others, Nils Stensen: "The heart of a young bird was so vigorous that it jerks had not in the least lost their quickness or strength still two hours after the exposure [and opening of the animal's thorax]." ${ }^{56}$ Questions such as what animals were used for vivisections by Gottwald in Danzig, which systems and organs he examined and tested, and how often he did such things are impossible to answer because of a lack of source materials. ${ }^{57}$ One may speculate that Gottwald was interested in the research into lymphatic vessels. As a student under the tutorage of Sylvius he had taken part in the debate De vasis lymphaticis... (1661), ${ }^{58}$ a fashionable and important

(3 inventory items), creta (7 inventory items), rubrica (1 inventory item) and ochra. Terrae sigillatae (50 inventory items), lemnia (3 inventory items), lac lunae (3 inventory items), again ochra (2 inventory items), lutum (10 inventory items), bolus (3 inventory items) and nil album (4 inventory items) are included amongst medical raw materials (ibidem, ff. $7 \mathrm{v}-8 \mathrm{r})$.

54 Cf. the print depicting a louse. Musaeum Gottwaldianum, http://pbc.gda. pl/dlibra/ docmetadata? $\mathrm{id}=2467 \&$ from $=\&$ dirids $=1 \&$ ver_id $=\& \mathrm{lp}=1 \& \mathrm{QI}=($ accessed: 01.03 .2018$)$.

55 G. Kohfeldt, Eine akademische Ferienreise, p. 23.

56 Qtd in: Nicolaus Steno: Biography, p. 95-96.

57 We know that, for certain, he performed dissections on dead seals, porpoises, piglets, kittens, turtles etc. The material about the vivisections themselves is incomplete.

58 Disputatio VIII. De vasis lymphaticis ac lympha (cf. footnote 16). 
topic within northern European medical circles, and also in Royal Prussia. ${ }^{59}$ He most certainly, as did his master and friends, undertook research into digestion and blood circulation. ${ }^{60}$ Possibly he also involved himself in studies into infusions and the effects of cold that had been undertaken by other Danzig doctors of medicine including Israel Conrad. ${ }^{61}$

Leiden was, during the period when Christoph Gottwald was a student, one of the most important centres for the teaching of medicine and anatomy. When Sylvius lectured there the town was constantly visited by students "ex Ungaria, Moscovia, Polonia, Germania, Dania, Suecia, Helvetia, Italia, Gallia, Anglia." ${ }^{2}$ Amongst those who graduated there were numberous eminent doctors and anatomists of the second half of the $17^{\text {th }}$ century and the first decades of the $18^{\text {th }}$ century: Reinier de Graaf, Nils Stensen, Jan Swammerdam, Ole Borch, Robert Sibbald, Christian Ruduednick, Burchard de Volder and many others. ${ }^{63}$ Their colleague from

59 Cf. the correspondence of Philipp Jacob Sachs von Loewenheimb with Thomas Bartholin (Copenhagen) and Georg Seger (Toruń/Thorn-Gdańsk/Danzig). University of Wrocław Library, Ms. R405, ff. 71, 267-269.

60 See selected printed disputations by students from Danzig studying medicine in Leiden at the time when Sylvius taught there. BG PAN, XIX.q.83b.

${ }^{61}$ The famous dissertation by Israel Conrad on the subject of cold was iatrochemical in character. And also Gottwald was fascinated by iatrochemistry. Often in this work, one prepared for the needs of the Royal Society in London, there appeared ties to the works of Gottwald's teacher Frans de la Boë Sylvius, and also Robert Boyle, Pierre Gassendi and Johann Glauber. Cf. Israeli Conradi Med. Doc. Dissertatio medico-physica de frigoris natura et effectibus, Olivae 1677; BG PAN, Ms. 673, f. 121a-123a. It is also worth noting that similarly to Gottwald, Conradi was a graduate of Leiden University, where on $13^{\text {th }}$ of March 1659 he presented his thesis De sanguine, in which he discussed the iatrochemical propertiesof blood and chyle as well as the matter of blood circulation. What is important is that Gottwald also cooperated with other Danzig doctors of philosophy and medicine in order to create an academic body of a college format. See BG PAN, Ms. 703, ff. 96v-99v.

62 L. Schacht, Oratio funebris in obitum Franc. de le Boe Sylvii, Leiden 1673, p. 25.

63 About these and other pupils of Sylvius cf. e.g. E. D. Baumann, Francois Dele Boe Sylvius, Leiden 1949; Ch. L. Heesakkers, The Amsterdam Professors and Other Friends of Johannes Blasius. The album amicorum of Johannes Blasius, Amsterdam, University Library, Ms. VJ 50, "Lias: Sources and Documents Relating to the Early Modern History of Ideas" 1982, vol. 9, p. 179-231; E. Jorink, Modus politicus vivendi: Nicolaus Steno and the Dutch (Swammerdam, Spinoza and Other Friends), 1660-1664, in: Steno and the Philosophers 
the times of their medical travels was a twenty-something young man from distant Danzig who in the future was to become one of the most important collectors and anatomists of the Polish Lithuanian Commonwealth. It was to him that Sylvius directed the words: "Betet fleißig, vertrauet Gott, so werdet ihr Spielende zu großen Wissenschafften gelangen." ${ }^{64}$

trans. by Guy Russell Torr

\section{ANNEX}

The $17^{\text {th }}$-century anatomy surgery of Christoph Gottwald as well as his anatomical-surgical instruments and etching tools.

Drawings from: Musaeum Gottwaldianum, http://pbc.gda.pl/dlibra/docmetadata?id $=$

2467\&from $=\&$ dirids=1\&ver_id $=\& 1 \mathrm{p}=1 \& \mathrm{QI}=$ (accessed: 01.02.2018);

Museum Gottwaldianum, http://docnum.u-strasbg.fr/cdm/ref/collection/ coll13/id/44005 [access: 01.02.2018].

Descriptions of the drawings from: Iconum Specimina quas pro Museo Anatomico... [etc.], Bibliotheek Museum Boerhaave (Leiden), call number BOERH a 527, pages not numbered.

Series, eds. M. Laerke, R. Andrault, “Brill's Studies in Intellectual History,” vol. 276, Leiden 2018, pp. 13-44.

${ }^{64}$ Personalia, pages not numbered. 

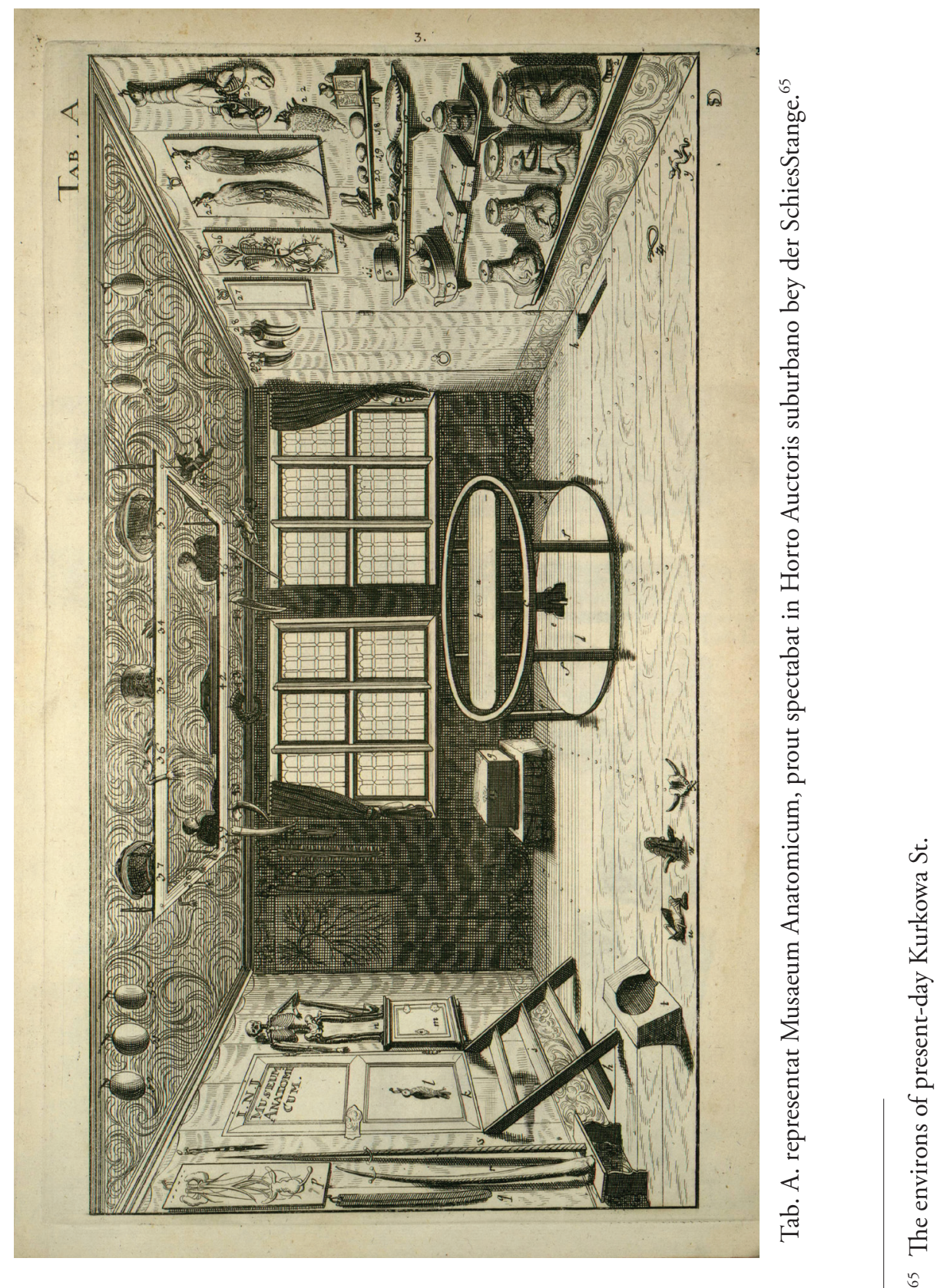


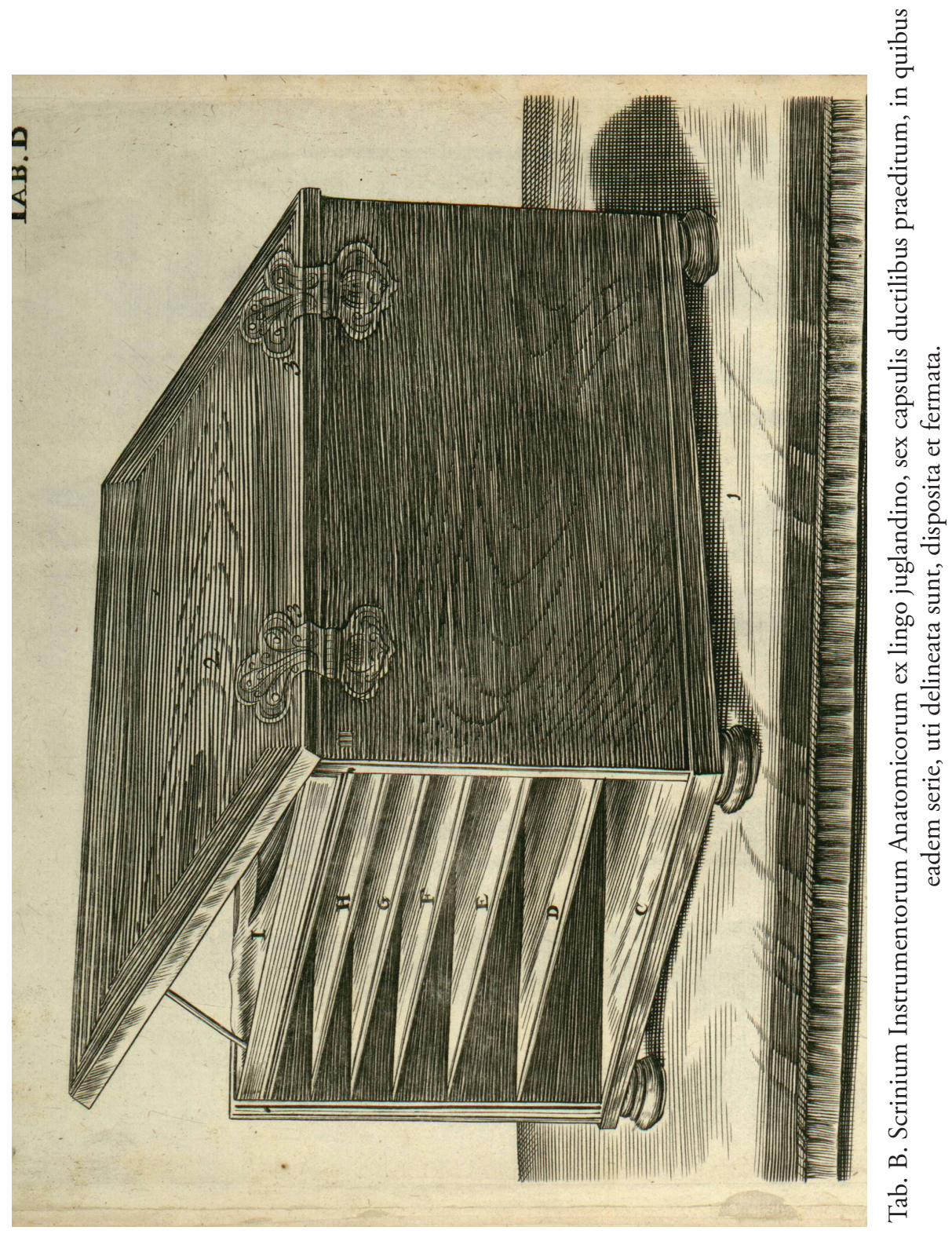




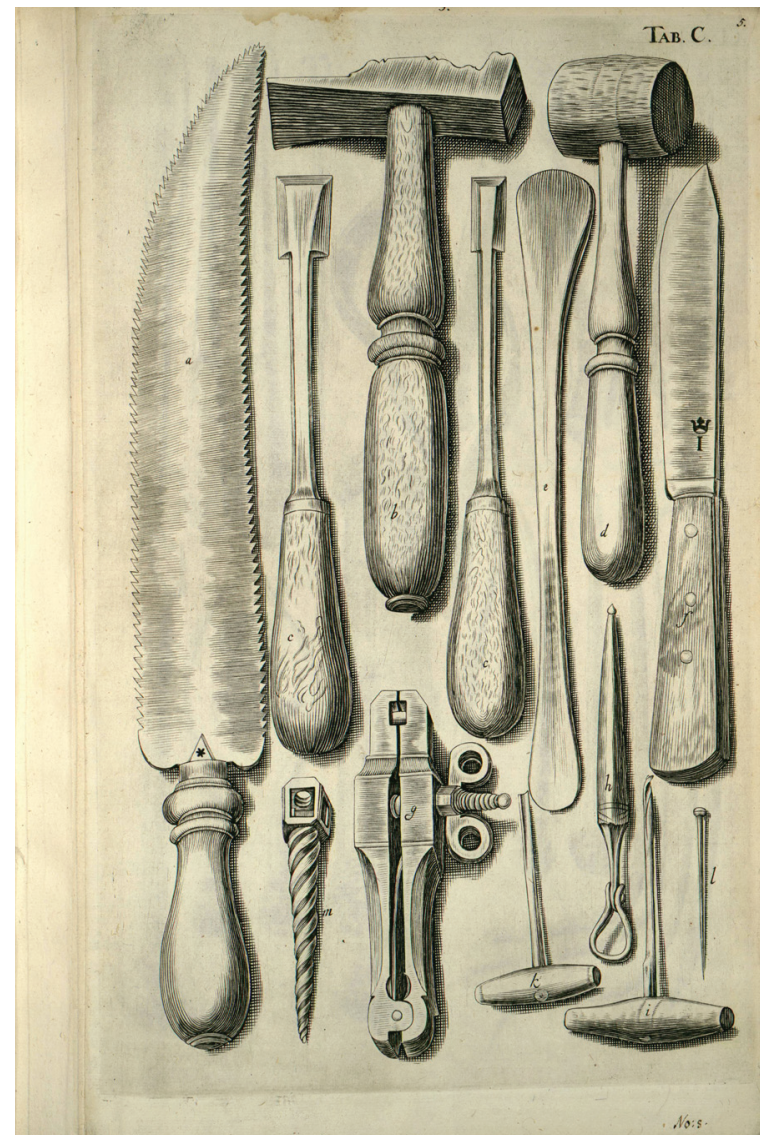

Tab. C.

a. Serra bisecalis, ab utraq[ue] acie dentate.

a. Malleus ferreus.

b. Scalprum fissorium majus, ein durchschlag. Turunda ein Meißel.

c. Scalprum fissorium minus.

d. Malleus ligneus; Tudeus, s. Mateola.

e. Intrumentum sublevatorium pro cranio aperiendo.

f. Culter major et fortis ad findendas cartilagines etc.

g. Retinaculum, ein Feilkloben, quo styli et alia instrumenta firmant[us].

h. Lima pro acuendis cultris; ein WatzStahl.

i. Ferbera imbricata, ein Böhrer.

k. Terbera rotunda; ein Holböhrer.

1. Acus capitata, Eine HefftNadel.

m. Cochleare Instrumentum ad viva corpora firmanda. 


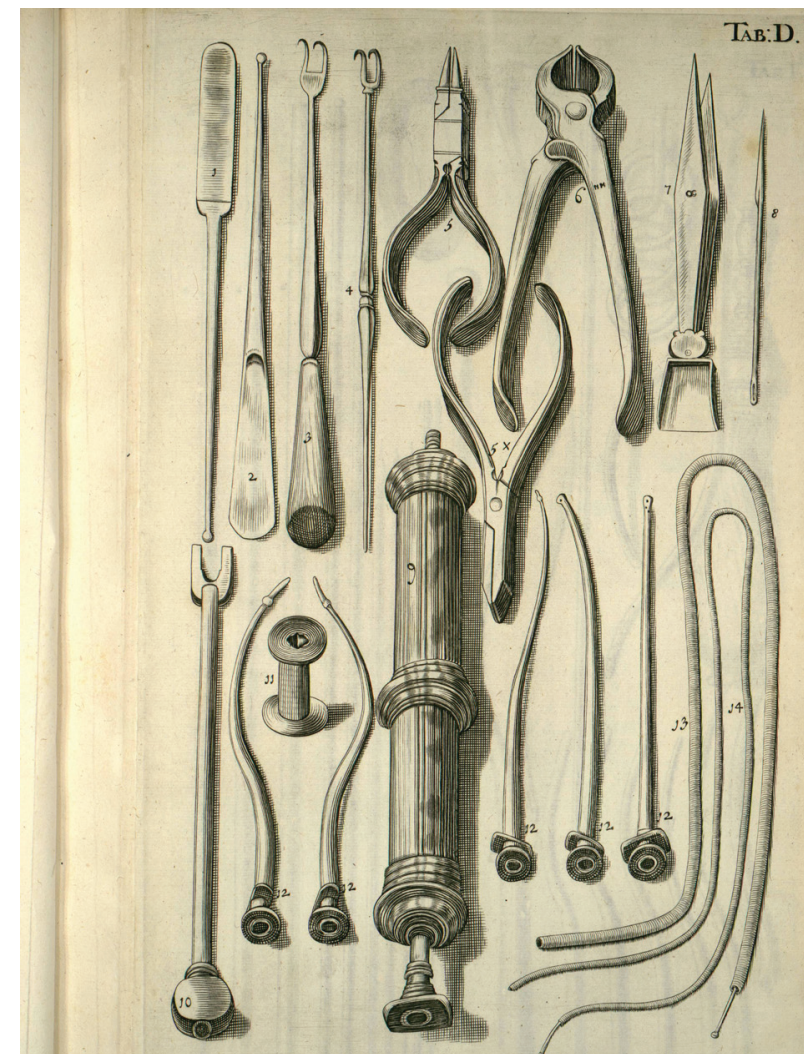

Tab. D.

1. Spatula anea. S. Specillum latum, s. Ligula 2. Spatula ferrea.

3. Hamulus cum Manubrio, s. Retinaculum.

4. Hamulus cum Stylo.

5. Forcipula incurvatoria, Eine Bind-Zeuge 5.+ Forcipula plana.

6. Volsella, Eine LeisZangen. Tricholabium Hahr auszuziehen 7. Forceps parva, eine KornZange.

8. Acu triangularis, instar Discerniculi; ein Haarscheitel 9. Sipho.

10 Clavis Siphonis, quo Tabuli firmant[us]

11. Matricula Siphonis, pro alio liquorum genere.

12. Tabuli pro Siphone varii majors et minoris.

13. Instrumentum flexile cum suo epistomio. 14. Aliud multo minus, d. ad modum necessarium. 


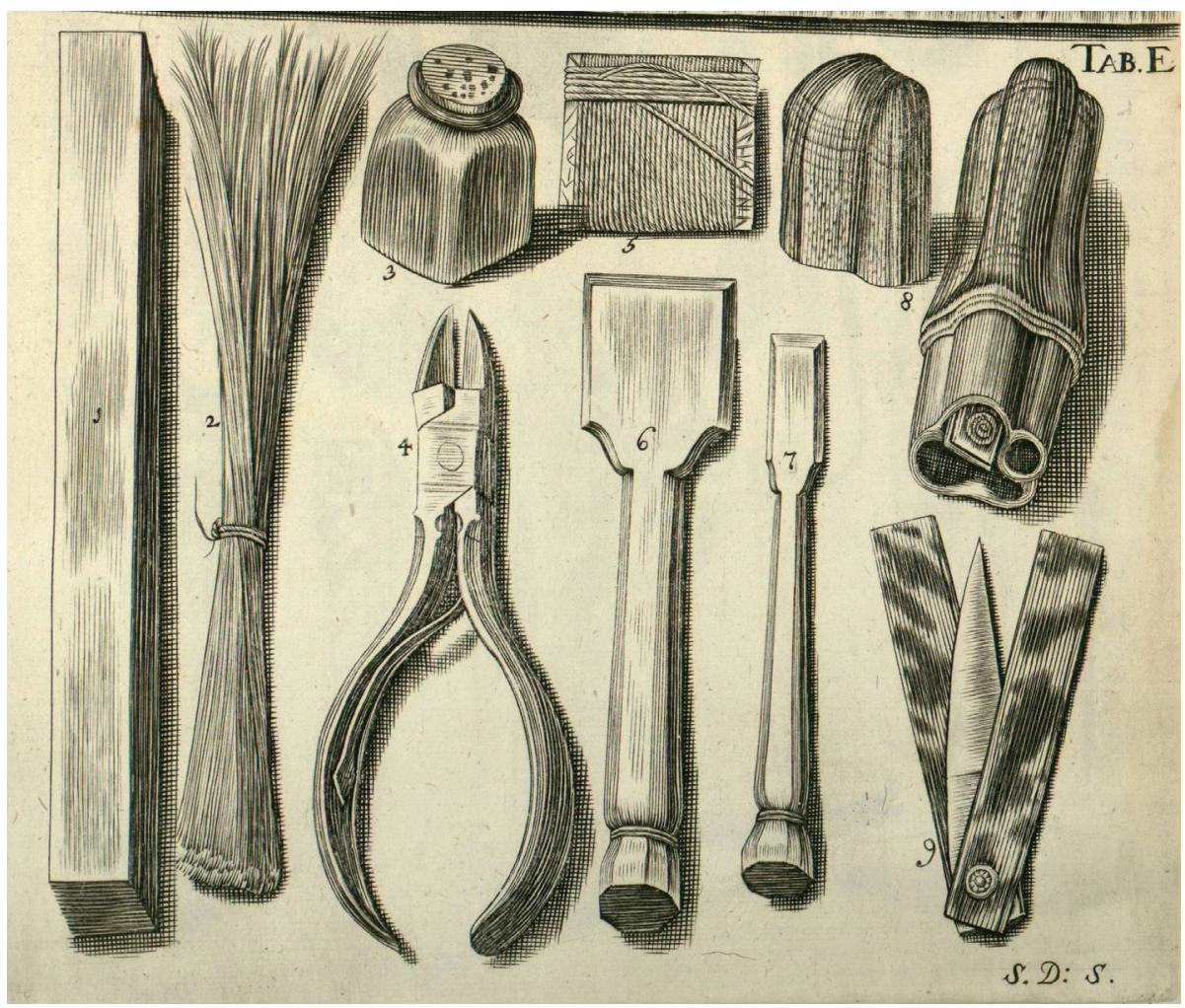

Tab. E.

1. Cos olearis

2. Fasciculus ex setis nullis [?]

3. Lagenula cum Oleo Olivo.

4. Forceps incisoria.

5. Glomus filamentorum ad ligaturas.

6. Scalprum separatorium, Ein Meißel.

7. Idem minus.

8. Receptaculum Scalpellorum cum lancetta phlebotomica.

9. Instrumentum incisorium, Lanceola alias, Scultet Arm Ch. T. 19. ${ }^{66}$

66 J. Scultetus, Armamentarium chirurgicum, Ulmae Suevorum 1655, http://digital. lib.uiowa.edu/cdm/ref/collection/jmrbr/id/2003 [access: 01.03.2018]. 


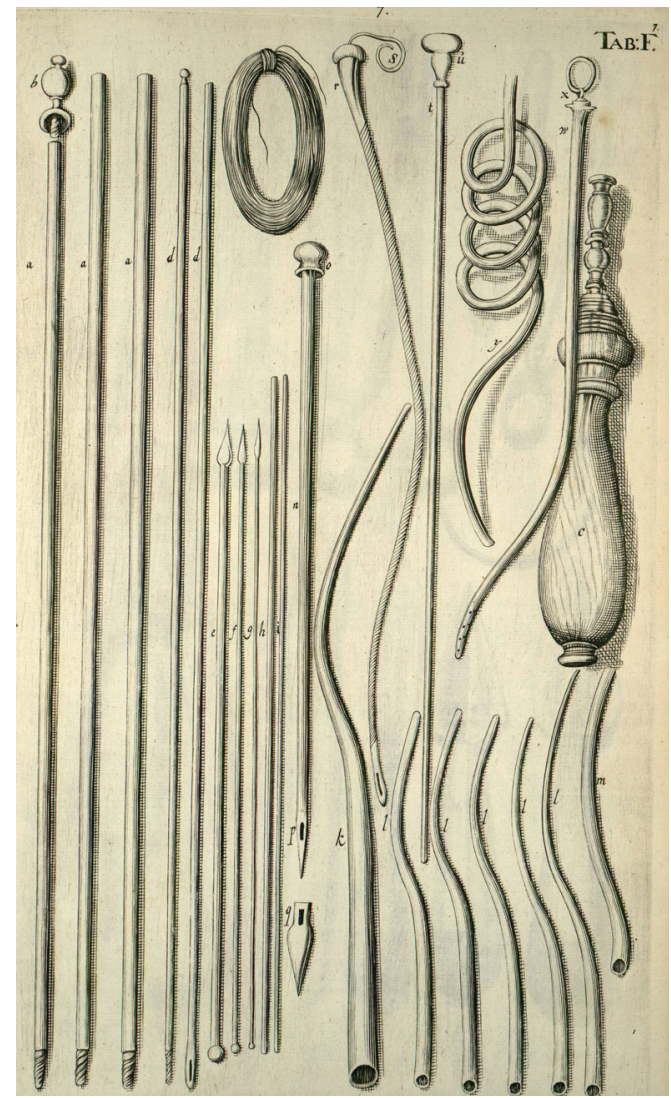

Tab. F

a.a.a.b.c. Stylus demonstratorius, qui ter prolongari potest.

d.d. Styli transmissorii cum perforatione in altero extremo.

e.f.g.h. Styli argentei varii exploratorii.

i. Stylus exploratorius plumbeus ut alis ex borba ceti l. cornu flexili.

$\mathrm{k}$. Tubulus argentus pro inflandis ductibus etc.

1.1.1. etc. Tabuli minores majori intrudendi pro minoribus vasis.

m. Amplior Tubulus ad inflandam Vesicam etc.

n. Instrumentum Paracenteseos argenteum, cum suo epistomio o. et cuspide rotundaargentea perforata $\mathrm{p}$.

q. Acumen Chalybeum in formam Lancettae.

r. Catheter flexilis argenteus s. filum argenteum s. epistomium.

t. Catheter flexilis alius ex cornu excavato et mallefacto paratus cum filo suo. u.

w. Catheter ordinaries argenteus curu suo epitomio. $\mathrm{x}$.

y. Candela cerea tenuis exploratoria. 


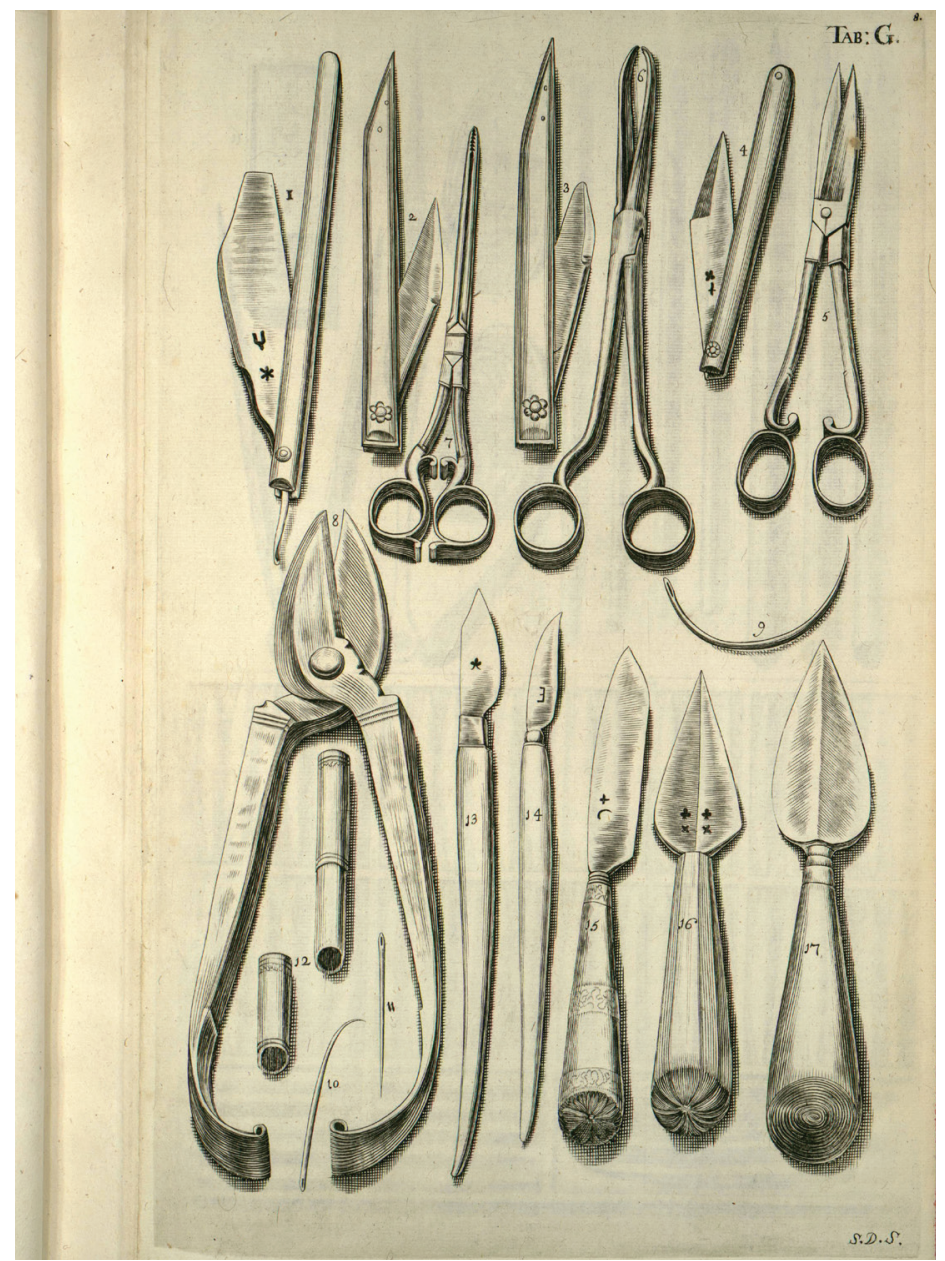

Tab. G.

1. Novacula.

2. Cultellus pro explicandis ductibus.

3. ---.---- pro separandis musculis.

4. --.------- pro divellendis visceribus.

5. Forfices et Forficulae.

6. Forces extractoria incurvata, quae et Tenacula dicit[us] Hildano. ${ }^{67}$

67 Wilhelm Fabry known as Hildanus (1560-1634) - a German surgeon considered to be one of the fathers of modern surgery. The city surgeon in Berne and the author of, among other things, Observationum et Curationum Chirurgicarum Centuriae, Basel 1606. 


\section{Alia dentata.}

8. Forfex major pro discindendis costis.

9. Acus incurvata semilunaris.

10. Acus alia incurvata.

11. Acus recta triangularis.

12. Acuum reservatorium cum suo claustro.

13. Scalpellum Anatomicum, cultellus separatorius acine lunata.

14. Scalpellum excisorium s. incurvu[m] ad certilagines etc.

15. Cultellus ad cutim removendam.

16. 17. Scalpella Myrthea.

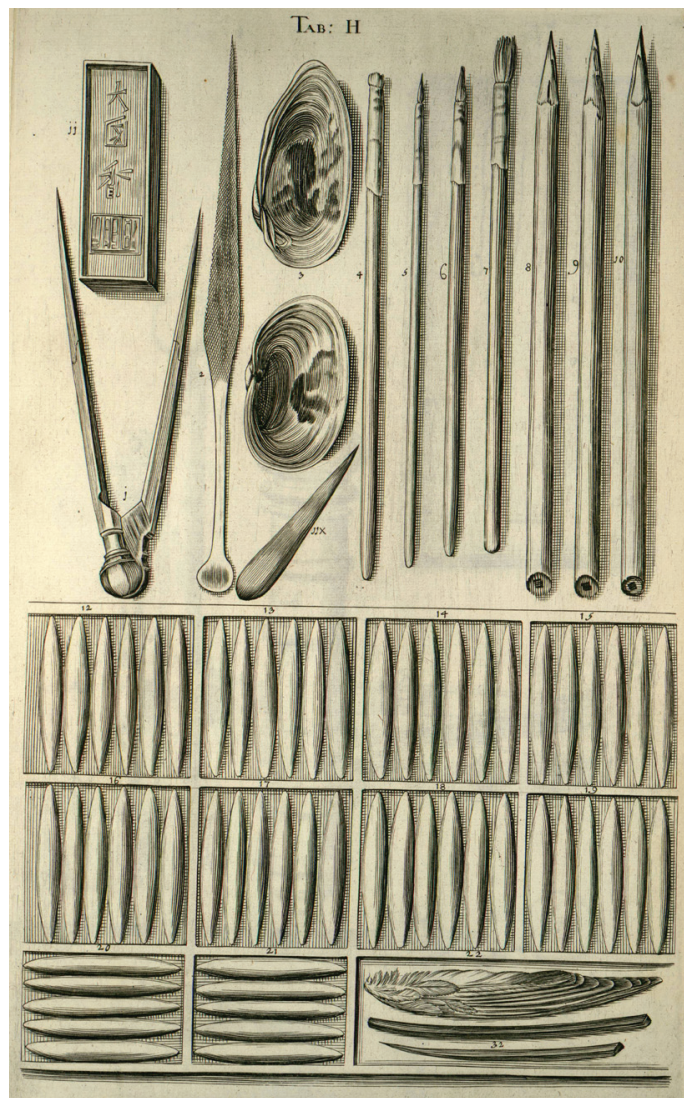

Tab. H. Haec capsula destinata est supellectili necessariae ad delineandas figuras non coloratas et coloratas, prout Curiositas Observationis requirit.1. Circinus.

2. Lima laevis ad acuendos carbones, cretas etc.

3. Mytuli s. Conchae duae pro miscendis coloribus. 
4. Penicillum obtusum ad siccos colores divellendos. 5.6.7. Minor, medius et major Penicillus ad colores dilutos.

8. Creta Gallica alba lingo excepta.

9. Rubrica fabrilis nativa.

10. Cerussa Hungarica.

11. [E]x Creta nigra mineralis.

jj. Atramentum indicum. ${ }^{68}$

Sequunt[us] Colores compacti arte facti in forma turundarum, quorum ope colorant[us[ figurae, ut naturae magis convenientes ${ }^{69}$ videantur. Hi Colores Crayons s. Creons vocantur, quos ante 40 et quod excurrit Annos Celebris Pictor Samuel Niedenthal hic Gedani egregie componere novit.

12. Ex rubro: Sanguineus, ${ }^{70}$ Rubricatus,${ }^{71}$ Ruffus,${ }^{72}$ Rutilus, ${ }^{73}$ Flammeus,${ }^{74}$ Cinnabarinus. ${ }^{75}$

13. Ex rubro Pallescentes. Cujusvis priorum dilutior et saturatior.

14. Ex Purpura: Coccineus, ${ }^{76}$ Lacceus obscurus et dilutior, violaceus ${ }^{77}$ amethystinus, ${ }^{78}$ Spadiceus. ${ }^{79}$

15. Ex Purpura pallescentes: Rosei ${ }^{80}$ coloris quadrupli cessaturatiores et dilutiores, Amethystinus item et Spadiceus color albo mixtus.

68 The inscription on the inkwell is more than likely the actual name of the producer. It is not known what the central logographic sign signifies. The first from the top means 'large,' the third 'incense.' At the bottom visible is the producer's stamp. I would like to thank the Japanologist Radosław Bolałek for his consultation on this matter.

69 The ending "is" a changed "es".

70 Blood-red. An appropriation in the English names of particular pigments has been given on the basis of an analysis of German names for colours as identified by: W. J. Jones, German Colour Terms: A Study in Their Historical Evolution from Earliest Times to thePresent, Amsterdam 2013; idem, Historisches Lexikon deutscher Farbbezeichnungen, vol. 2-5, Berlin-Basel-Munich 2013. On the dyes used in the Danzig dyeing industry see The State Archive in Gdańsk, AmG 300, R/Vv,q33, ff. 3-30.

71 Red.

72 Yellowish-red, rust-coloured.

73 Fire/oxide red.

74 Flaming red.

75 Cinnabar.

76 Scarlet or carmine.

77 Purple/violet.

78 Amethyst.

79 Chestnut.

80 Rose, pinkish. 
16. Ex Nigro: diversi generis et mistura Nigrum, Ater ${ }^{81}$ Niger, ${ }^{82}$ pallino Furvus, ${ }^{83}$ Murinus $^{84}$ et Cinereus. ${ }^{85}$

17. Ex Albo: Nitidus, ${ }^{86}$ Niveus,${ }^{87}$ Pallidus,${ }^{88}$ luridus ${ }^{89}$ ex luteo, canescens. ${ }^{90}$

18. Ex Flavo: Ravus, ${ }^{91}$ Luridus, ${ }^{92}$ Aureus,${ }^{93}$ Luteus, ${ }^{94}$ Croceus, ${ }^{95}$ Aneus. ${ }^{96}$

20. ${ }^{97}$ Ex Coreuleo: Indicus, ${ }^{98}$ Cyaneus, ${ }^{99}$ Caeruleus, ${ }^{100}$ Lividus (bleyfarbe),${ }^{101}$ Caesius, ${ }^{102}$ Violaceus.

19. Ex Flavo albescentes: Gilvus, ${ }^{103}$ Melleus, ${ }^{104}$ Cereus, ${ }^{105}$ et magis pallescente.

21. Ex Viridi saturate herbaceous, ${ }^{106}$ dilutes idem, prasinus, ${ }^{107}$ Carpasin $[\mathrm{u}] \mathrm{s},{ }^{108}$, Vitreus. ${ }^{109}$ 22. Ala perdicum pro delendis Carbonum ductibus.

23. Carbones ad figurandum.

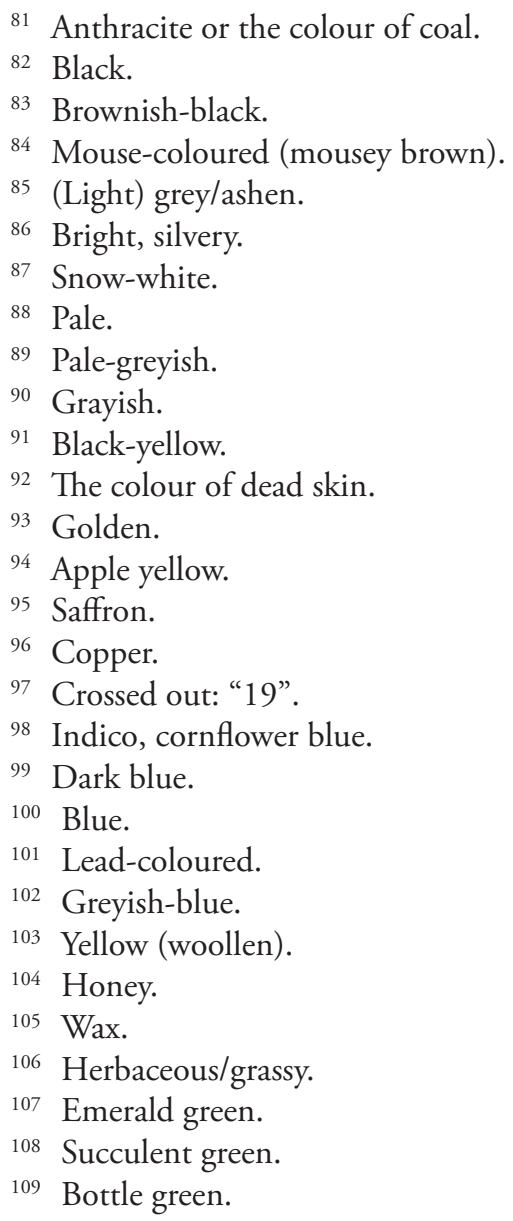




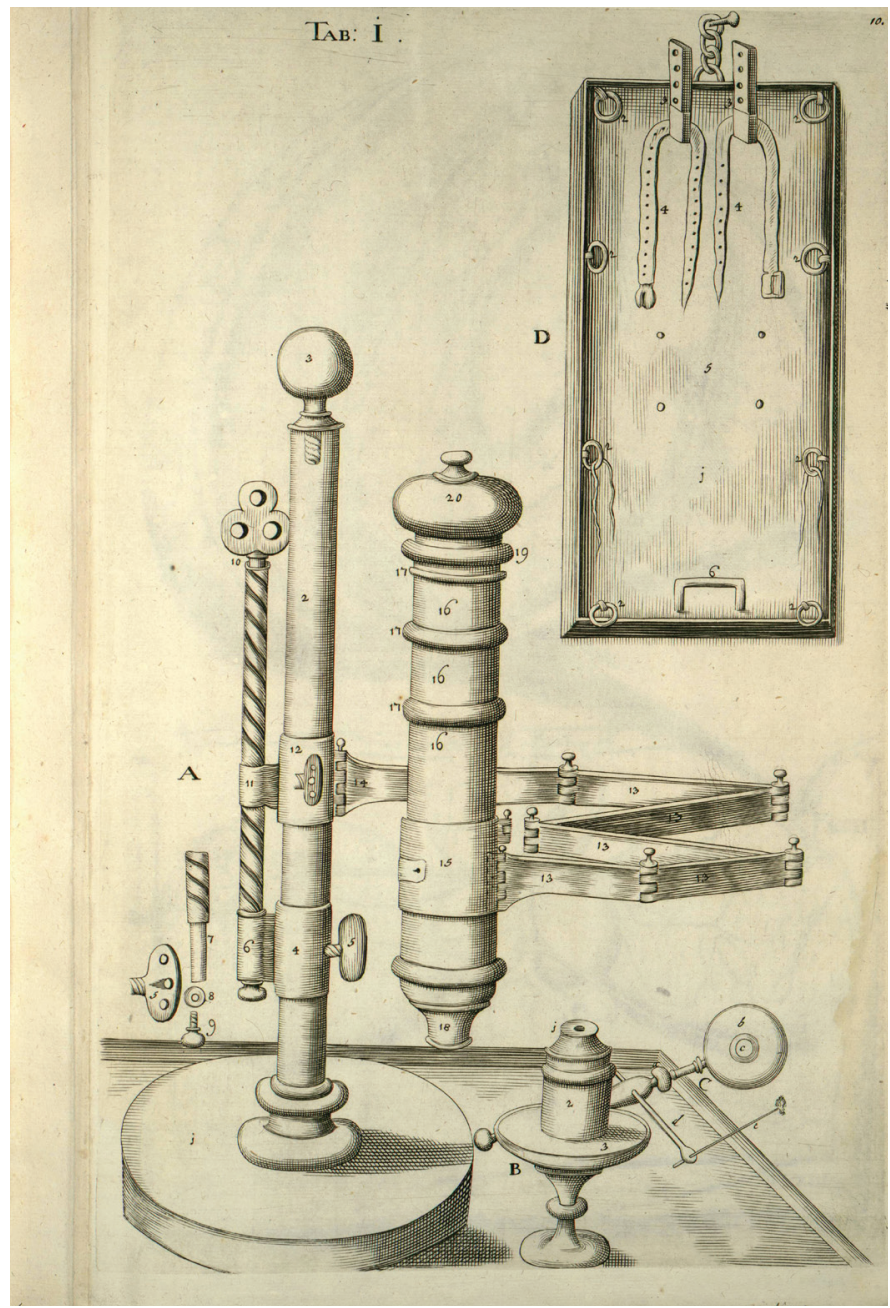

Tab. I

A. Misroscopium majus mobile tribus tubis invicum intrusis constrans.

B. -...-_-_-_-- minus manuale una lente constans et tubo vitreo.

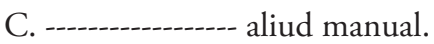

D. Mensa An atomica pro vivis Animantibus.

3.3. Fulera duo inter quae caput animalis positum stylo ferreo per foramino misso stringitur.

5. Quatuor foramina $\mathrm{p}[\mathrm{er}] \mathrm{q}[\mathrm{ue}]$ ligaturis abdomen stringitur ne violentia motus animalis sectione $[\mathrm{m}]$ impediat. 
